Tatiana S. Shipunova

\title{
Principles of public-private partnerships as a form of social entrepreneurship
}

\section{KEYWORDS}

social entrepreneurship;

public-private partnership;

principles;

social responsibility;

stakeholders;

sustainable development;

corporate effectiveness
FOR CITATION

\section{ABSTRACT}

Social entrepreneurship takes many forms as a type of entrepreneurship. The least scientifically substantiated economic form of social entrepreneurship is a public-private partnership in the field of intangible services. The study aims to determine the principles of public-private partnerships as an economic form of social entrepreneurship.

To achieve the aim, the method of comparative analysis of the principles of public-private partnership by country and by the application in Russian scientific research was used. The principles of social entrepreneurship, taking into account economic activities, factors of legitimacy, and the context of the application were also compared.

According to foreign scientific publications, chronological analysis of the social responsibility concept, stakeholders and sustainable development, which all affect the formation of entrepreneurial culture, has been carried out.

As a result, the principle of corporate efficiency was formed, which includes six components: areas of corporate social responsibility, levels of microeconomic responsibility, stakeholders, social issues management, corporate social sensitivity, corporate social activity impact assessment. The principle of corporate efficiency can be applied in the preparation of recommendations on the interaction of public and private socio-entrepreneurial structures, which indicates its practical significance.

Further research may be carried out on the formation of tools that operationalize the mechanism of public-private partnerships as a form of social entrepreneurship based on the principle of corporate effectiveness.

Shipunova, T. S. (2020). Principles of public-private partnerships as a form of social entrepreneurship. Economic consultant, 29 (1), 49-56. doi: 10.46224/ecoc.2020.1.5 


\section{INTRODUCTION}

$\mathrm{T}$ he relevance of substantiating the principles of partnership between public and private individuals is related to the coordination of efforts of public and private partners for the effective implementation of social and entrepreneurial initiatives in market conditions.

Social entrepreneurship takes many forms as a type of entrepreneurship $[1 ; 2]$. In a previously published study, such an economic form of social entrepreneurship as a public-private partnership in the field of intangible services has been studied [3]. It was found that publicprivate partnerships and social entrepreneurship had the same elements, namely, mission, results, processes, resources, and sectors of economic activity. They take the characteristics of business entities into account. Using a systematic approach, a dialectical unity between publicprivate partnership, as a form, and social entrepreneurship as content has been established. The dialectical unity of public-private partnerships as a form, and social entrepreneurship as a content, lies in the inseparability of their form and content, the ambiguity of the relationship between them, the contradictory nature of unity and optimal development [3; 4].

The characteristics of business entities are more studied in social entrepreneurship than in public-private partnerships. This confirms the ambiguity of the connection and the inconsistency of the unity of public-private partnerships, as a form, and social entrepreneurship, as the content. To better match the form and content of the two economic phenomena under consideration, the characteristics of business entities in a public-private partnership should be investigated in more detail.

If the characteristics of business entities as a subsystem of the social entrepreneurship system [3] are considered, then the elements such as motivation, the ability to find opportunities, and make changes using leadership skills [5] can be distinguished. Motivation, as part of the entrepreneurship culture, is formed on certain principles. In this scientific article, the aim is to determine the principles of public-private partnership as an economic form of social entrepreneurship.

\section{MATERIALS AND METHODS}

The research materials used were Russian and foreign periodicals, abstracts of dissertations by Russian scientists for the degree of candidate of economic sciences, etc.

To achieve the goal, the authors used the method of comparative analysis of the principles of public-private partnership by country and by the application in Russian scientific research, as well as the principles of social entrepreneurship, taking into account economic activities, factors of legitimacy, the context of application. A chronological analysis of the concept of social responsibility, stakeholders and sustainable development, affecting the formation of business culture, is made based on foreign scientific publications. 


\section{RESULTS}

The need to formulate principles for the creation and functioning of public-private partnerships is recognized at the global level. The principles of effective management applied in the implementation of PPP projects include stakeholder engagement, following the rules without harming the environment and the public, transparency in the decision-making process, accountability to the public, fairness in following the rules by all members of the society, efficiency involving the use of "limited human and financial resources without loss, delay or damage, or without harming future generations", sustainable development [32].

At the country level, while determining the PPP policy, principles are established that ensure the implementation of PPP projects and constitute a code of conduct following which the PPP project will be implemented. These are some standards by which those responsible for PPP implementation should be accountable. The principles confirmed by some countries (Australia, Brazil, Germany, Indonesia, Peru, Russia) in their concepts and policies in the field of PPP coincide in transparency, risk sharing and competition in the field of PPP. The operationalization of principles is manifested in rules (instructions, regulations) and processes. For example, in Germany, an instrument for operationalizing the principle of efficiency and economy is the analysis of the economic feasibility of any government initiatives related to the budget and financial effect, including PPP, simultaneously with the analysis of alternative projects [6].

Since the object of PPP is state assets or services, projects attract people interested in their effective implementation, as well as reacting differently to the implementation of PPPs at different stages. In this regard, it is important to involve stakeholders in advising on the value of the project for society and reducing information risks. Effective dialogue with stakeholders is facilitated by the principles of clarity, coverage of all relevant groups of stakeholders, publicity of the PPP project, sufficient time for consultations with stakeholders and feedback [6].

In the abstracts of dissertations, Russian researchers (see Table) also establish the principles of PPP. As the authors study the nature of PPP in the field of intangible services, the specifics of the industry in which PPP can be formed should be taken into account. The principles of PPP can be divided into:

- economic (management, distribution of project income, quantitative measurability of PPP performance indicators, project evaluation, socio-economic innovation, transparency of financial activities),

- social (reduction of social risks in the labor market), ethical (trust, responsibility, quality, pragmatism, openness),

- activity (organization, integration, partnership, division of spheres, dynamism).

In the field of social entrepreneurship, researchers (see Table) recognize either the very phenomenon of social entrepreneurship as a principle, or identify categories of principle. The principles of social entrepreneurship are applied in such areas as education, healthcare, 
tourism, and hospitality. The factors of the legitimacy of the principles of social entrepreneurship are the concepts of social responsibility, sustainable social and economic development, the strong dependence of non-profit organizations on philanthropic and state funding, and the strengthening of the requirements of stakeholders. The context in which researchers apply the principles varies, including, but not limited to promoting social and economic growth, sustainable development of economic phenomena, and measuring social impact.

Table Principles of public-private partnerships and social entrepreneurship

\begin{tabular}{|c|c|}
\hline PPP principles & Principles of social entrepreneurship \\
\hline $\begin{array}{l}\text { - copyright principles of activity: regionalization, } \\
\text { social partnership, transparency of financial } \\
\text { activities, integration [7] } \\
\text { - } \text { principle of pragmatism, organization, } \\
\text { transparency, quantitative measurability of } \\
\text { PPP performance indicators, differentiation of } \\
\text { methods for assessing projects and PPP partners } \\
\text { [8] } \\
\text { - } \text { principle of distribution of project income [9] } \\
\text { - } \quad \text { principles of agent theory of stakeholders [10] } \\
\text { the quality of services, socio-economic } \\
\text { innovation, reducing social risks in the labor } \\
\text { market [11] } \\
\text { principles of selection, diagnosis, a system of } \\
\text { indicators for monitoring the assessment of PPP } \\
\text { projects throughout their entire life cycle [12] } \\
\text { principles of transparency, trust, social } \\
\text { responsibility [13] } \\
\text { principles of the division of responsibilities } \\
\text { between the participants in the partnership, } \\
\text { the dynamism and structural integrity of the } \\
\text { organizational structure [14] } \\
\text { principle of trust management [15] }\end{array}$ & 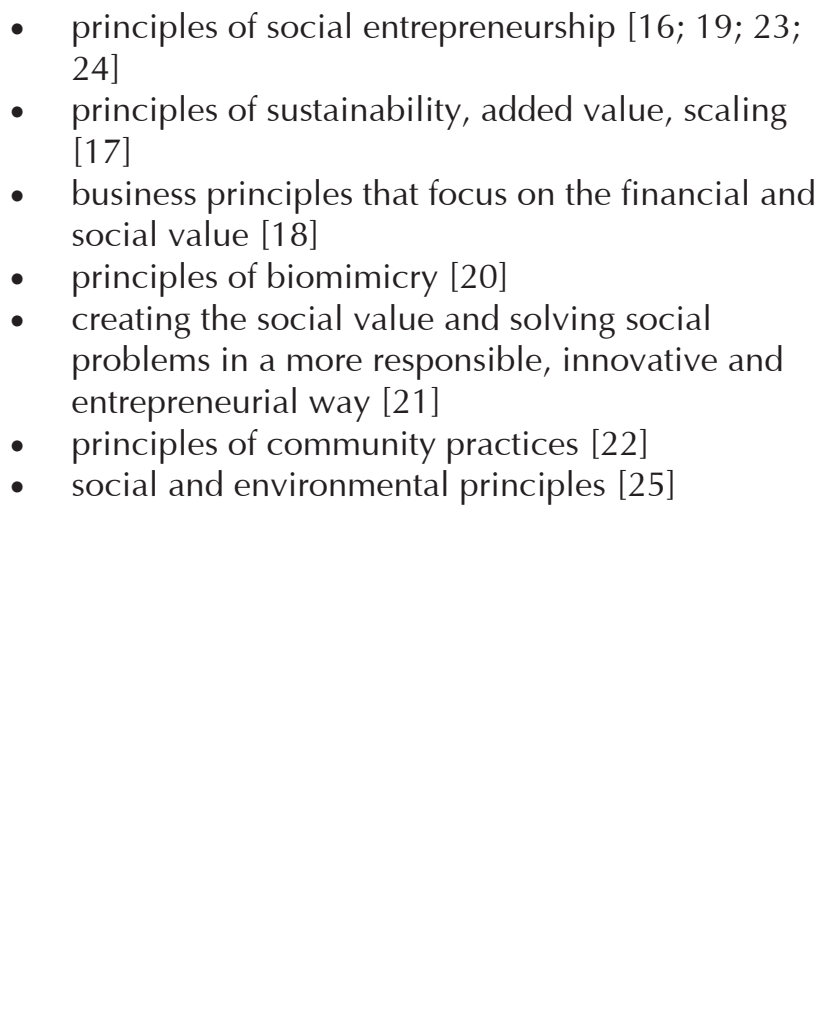 \\
\hline
\end{tabular}

Business trends affect the formulation of principles. Since the mid-1950s, changes in the social environment influenced the foundations of the existence of organizations as economic entities legitimized by society. In the 1970s, scientists developed the concepts of corporate social responsibility, corporate social susceptibility, corporate social activity. In the 1980s, alternative topics appeared in the field of business social responsibility, namely, corporate social policy, business ethics, stakeholder theory. The 1990s and 2000s proclaim an era of global corporate citizenship and sustainable development [26].

The concept of corporate social responsibility has the longest history of the development of views with various interpretations. Social responsibility is defined as the circle of business responsibilities to society on the economic, legal, ethical and discretionary aspects of business activity. Justification of the types (categories) of corporate social responsibility [27] contributed to the recognition of social responsibility as a principle [28]. Categories of economic, legal, ethical and discretionary responsibilities evolve into principles. 
The principles of corporate social responsibility should be considered at the institutional, organizational and individual levels, at which, accordingly, the legitimacy, public responsibility and voluntary responsibility of company managers are fixed. The principle of legitimacy at the institutional level, the level of the main obligations of the company as a business organization, is determined by the "iron law of responsibility". The principle of public responsibility is formed at the organizational level. It is a level of specific conditions and relations of the company with the environment and means the responsibility of the business for results in the primary and secondary areas of contact with society. The principle of voluntary responsibility of managers [29], based on the consideration of people as active participants of the organization, is applied at the individual level.

A new perspective of the idea of social responsibility was given by the concept of stakeholders. It personalizes social responsibility by identifying specific groups or individuals that the business should take into account through the prism of corporate social responsibility [30].

The interaction of business and society is formed concerning certain problems or issues. The factors shaping social interaction include a comparison of social needs with corporate capabilities [27]. The social susceptibility of the organization forms the approach of implementing the principle of social responsibility [28]. The philosophical orientation of corporate social receptivity is the actions of the organization's leadership in the social sphere: reactive, protective, adaptive, and proactive. There are three characteristic behaviors of the company: to monitor and evaluate the environment, pay attention to the needs of interested parties and draw up plans and policies (strategies) in response to changing conditions [29].

Current trends in the development of corporate social responsibility are strengthened by environmental concepts explicated in sustainable development, which is understood as the development that meets the requirements of today's generation without harming future generations in their needs and aspirations. The expanded concept of sustainable development at the microeconomic level includes economic, social, environmental dimensions and secondorder requirements [31].

\section{DISCUSSION}

Summarizing the development of views on the responsibility of business to society, it is possible to formulate the principle of corporate efficiency, consisting of the following components: areas of corporate social responsibility, levels of microeconomic responsibility, stakeholders, management of social problems, corporate social sensitivity, assessment of the impact of corporate social activity (see Figure).

The business operates in three areas of corporate social responsibility: required (economic and legal environment), expected (ethical environment), and desired (discretionary or voluntary), as well as at three levels of microeconomic responsibility: institutional, organizational, and individual. The stakeholders' requests of the present and future generations are taken into account: 
owners (founders), consumers, employees, the local community, suppliers, competitors, social activists, and society as a whole. The top management of the organization manages emerging social issues by identifying problems, analyzing problems and responding to problems. Corporate social susceptibility includes two types of processes: the degree of response (philosophical orientation) and types of actions (functional orientation). The degree of response to stakeholders' concerns varies. Based on their philosophical orientation, organization responses can be reactive, protective, adaptive, or proactive. Types of functional actions include environmental monitoring and assessment, attention to the needs of stakeholders, and the organization's strategy in response to changing environmental conditions. An assessment of the impact of corporate social activity is presented in corporate social policy (program) and findings reports.

Figure Stages of the formation of the principle of corporate efficiency

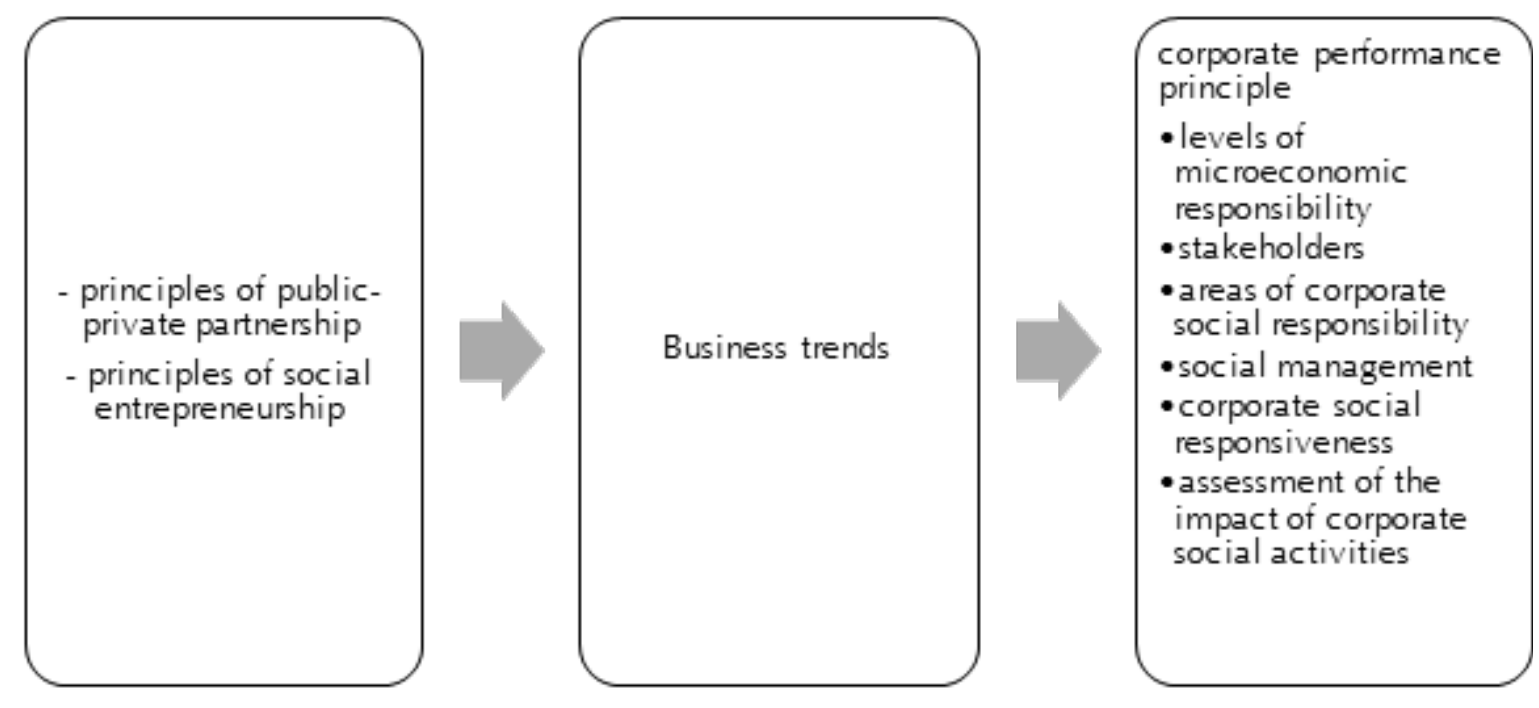

\section{CONCLUSION}

The dialectical correspondence of public-private partnerships and social entrepreneurship systematically proved in the previous scientific work of the author of this article strengthens the developed principle that forms the culture of interaction between business structures.

From a research point of view, the formulated principle of corporate effectiveness of publicprivate partnerships as a form of social entrepreneurship should be used to develop tools for public-private partnerships in the field of intangible services.

\section{ACKNOWLEDGMENTS}

The author expresses gratitude for the valuable comments to Saginova Olga Vitalievna Professor, Doctor of Economics, Professor of the Department of Entrepreneurship and Logistics of the Plekhanov Russian University of Economics. 


\section{REFERENCES}

1. Austin, J.E., Stevenson, H., \&Wei-Skillern, J. (2006). Social and Commercial Entrepreneurship: Same, Different, or Both? Entrepreneurship Theory and Practice, 30 (1), 1-22.

2. Saginova, O.V., \& Saginov, Y.L. (2012). On the Definition of Social Entrepreneurship. Russian Entrepreneurship, 6 (204), 47-54.

3. Shipunova, T.S., \& Kazantseva S.Y. (2018). Public-Private Partnership as a Form of Social Entrepreneurship. Russian Entrepreneurship, 19 (4), 907-918.

4. Alekseev, P.V., \& Panin, A.V. (2016). Philosophy: A Textbook (4th ed., revised). Moscow. (p. 592).

5. Dacin, P.A., Dacin, M.T., \& Matear, M. (2010). Social Entrepreneurship: Why We Don't Need a New Theory and How We Move Forward from Here? Academy of Management Perspectives, 24 (3), 36-56.

6. Public-Private Partnerships. Reference Guide. Version 3.0. (2017). Washington DC: International Bank for Reconstruction and Development. (p. 238).

7. Gerasimenko, O.A. (2012). The Development of Public-Private Partnerships in the Management of the Regional Educational System (Ph.D. Thesis). Belgorod. (p. 20).

8. Kanamgotov, A.E. (2014). Public-Private Partnership in the Service Sector (Ph.D. Thesis). Saint Petersburg. (p. 18).

9. Kolyagin, S.O. (2015). Improving the Tools for Assessing the Effectiveness of PublicPrivate Partnership Projects (Ph.D. Thesis). Tambov. (p. 23).

10. Kuznetsov, I.V. (2013). The Development of Public-Private Partnerships Based on the Distribution of Fixed and Variable Costs (Ph.D. Thesis). Kazan. (p. 23).

11. Leonova, Zh.K. (2013). Public-Private Partnership in Training for Small and MediumSized Enterprises (Ph.D. Thesis). Moscow. (p. 46).

12. Litovka, G.L. (2014). Evaluation of the Effectiveness of Public-Private Partnerships as a Factor of the Socio-Economic Development of the Region (Ph.D. Thesis). Kislovodsk. (p. 27).

13. Mansurov, A.M. (2015). Management of Enterprise Development in the System of PublicPrivate Partnership (Ph.D. Thesis). Saratov. (p. 28).

14. Savelyev, A.A. (2011). The Organization of Public-Private Partnerships in the Innovative Activity of Russia (Ph.D. Thesis). Moscow. (p. 24).

15. Sazykina, S.A. (2017). Development of Public-Private Partnerships Based on a Life-Cycle Contract (Ph.D. Thesis). Moscow. (p. 22).

16. El-Haddadeh, R., \& Weerakkody, V. (2012). Evaluating the Impact of Alternative Socially Innovative Public Sector Service Initiatives on Social Cohesion (ALLIANCE): A Research Note. Transforming Government: People, Process and Policy, 6 (3), 283-299.

17. Hadad, S., \& Drumea Gauca, O. 2014). Social Impact Measurement in Social Entrepreneurial Organizations. Management and Marketing, 9(2), 117-134.

18. Liu, S.S., Lu, J.-F.R., \& Guo, K.L. (2015). Using a Social Entrepreneurial Approach to Enhance the Financial and Social Value of Health Care Organizations. Journal of Health Care Finance, 40 (3), 31-46.

19. Mars, M.M. (2014). Extending the Legacy of the Land Grant Institution as a Social Innovation: 
A New Vision for University Technology Transfer and Entrepreneurship. Advances in the Study of Entrepreneurship, Innovation, and Economic Growth, 24, 209-226.

20. Patel, S., \& Mehta, K. (2011). Life's Principles as a Framework for Designing Successful Social Enterprises. Journal of Social Entrepreneurship, 2 (2), 218-230.

21.Peric, J., \& Delic, A. (2016). Developing Social Responsibility in Croatian Universities: A Benchmarking Approach and an Overview of Current Situation. International Review on Public and Nonprofit Marketing, 13 (1), 69-80.

22. Popoviciu, I., \& Popoviciu, S.A. (2011). Social Entrepreneurship, Social Enterprise and the Principles of a Community of Practice. Revista de cercetare si interventie sociala, 33, 44-55.

23. Sloan, P., Legrand, W., \& Simons-Kaufmann, C. (2014). A Survey of Social Entrepreneurial Community-Based Hospitality and Tourism Initiatives in Developing Economies: A New Business Approach for Industry. Worldwide Hospitality and Tourism Themes, 6 (1), 51-61. 24. Stecker, M.J. (2014). Revolutionizing the Nonprofit Sectorthrough Social Entrepreneurship. Journal of Economic Issues, 48 (2), 349-358.

25. Trivedi, C. (2010). Towards a Social Ecological Framework for Social Entrepreneurship. Journal of Entrepreneurship, 19 (1), 63-80.

26. Carroll, A.B., \& Shabana, K.M. (2010). The Business Case for Corporate Social Responsibility: A Review of Concepts, Research and Practice. International Journal of Management Reviews, 12 (1), 85-105.

27. Carroll, A.B. (1979). A Three-Dimensional Conceptual Model of Corporate Social Performance. Academy of Management Review, 4 (4), 497-505.

28. Wartick, S.L., \& Cochran, P.L. (1985). The Evolution of the Corporate Social Performance Model. Academy of Management Review, 10 (4), 765-766.

29. Wood, D.J. (1991). Corporate Social Performance Revisited. Academy of Management Review, 16 (4), 691-718.

30. Carroll, A.B. (1991). The Pyramid of Corporate Social Responsibility: toward the Moral Management of Organizational Stakeholders. Business Horizons, 34 (4), 39-48.

31. Steurer, R., Langer, M.E., Konrad, A., \& Martinuzzi, A. (2005). Corporations, Stakeholders and Sustainable Development I: A Theoretical Exploration of Business-Society Relations. Journal of Business Ethics, 61, 263-281.

32. United Nations Economic Commission for Europe. (2018). Practical Guidance on Effective Management in Public-Private Partnership. Geneva. (p. 128).

\section{INFORMATION ABOUT THE AUTHORS}

1. Tatiana S. Shipunova (Russia, Moscow) - Researcher. Plekhanov Russian University of Economics. E-mail: tnshp@mail.ru 